This is an Accepted Manuscript of an article published by European Yearbook of Minority Issues, available online: https://doi.org/10.1163/22116117_01701010

\title{
The 2018 South Tyrolean Election and the Consociational System of Democracy: Stability amidst Change?
}

\author{
Matthias Scantamburlo* \\ (Aston University)
}

\begin{abstract}
This article explores the impact of the 2018 South Tyrolean election on the autonomous province's consociational system of democracy. Implemented to tame centrifugal tendencies between the territory's language groups (German, Italian and Ladin), this system has since the 1990s been losing its inclusive capacity. While the Italian-speaking electorate has increasingly been underrepresented in the main decision-making processes, the German-speaking intra-ethnic electoral arena experienced the rise of secessionist parties. The article shows that, despite major changes affecting party politics in South Tyrol, the outcome of the 2018 election contributed to restore stability to the consociational system.
\end{abstract}

Keywords: territorial politics - ethnic politics - consociationalism - regional elections - South Tyrol

\footnotetext{
${ }^{*}$ Matthias Scantamburlo is postdoctoral researcher at Aston University (Birmingham) and team member of the Regional Manifestos Project at the University of Deusto (Basque Country).
} 


\section{INTRODUCTION}

The election to the provincial council, the Landtag, of the Autonomous Province of Bolzano/South Tyrol (hereafter South Tyrol), held on 21 October 2018, resulted in a major shift of power and important changes in the province's consociational political system. The South Tyrolean Peoples' Party (SVP), the main representative of the German- and Ladin-speaking minorities and regional key power player since 1945, for the first time in its history forms a government with an Italian-speaking right-wing party, the populist (Northern) League (LN). Despite gaining an absolute majority of seats up until 2013, the SVP has always ruled the territory in a coalition with a party representing the Italian national majority due to the consociational system, which establishes governmental inclusion of all linguistic groups. Yet in the past, it preferred to share power with Italian-speaking centre or centre-left parties. At the heart of these shifts in power relations lie major changes in the South Tyrolean parties and party system following up the 2018 elections. On the one hand, the decline in support for the South Tyrolean traditional governing parties, the SVP and the Democratic Party (PD), made the continuation of the incumbent coalition impossible. On the other hand, the changing preferences of the electorate led to the rise of new or reinvigorated challenger parties, such as the LN, which largely replaced the parties of the traditional opposition.

The aim of this article is to explore the main political dynamics that led to those changes and to assess how they affect the configurations of the South Tyrolean consociational system of democracy. Implemented to tame centrifugal tendencies, this system has for a decade been losing its balance, with the rise of secessionist parties in the German-speaking intra-ethnic electoral arena and a growing underrepresentation of Italian-speakers in the main decisionmaking processes. The article shows that, despite major processes of change affecting South Tyrolean politics, the outcome of the 2018 elections contributed to restore stability to the consociational system. Indeed, centrifugal tendencies have been weakened by the electoral losses of secessionist parties and the inclusion of all language groups has been improved. Not only have more Italian-speaking MPs moved into the Landtag, but also since the early 1990s a government party again represents an increasing percentage of the Italian-speaking electorate. Looking at theories of coalition formation, however, the article argues that the SVP-LN coalition has not only been formed on consociational principles, but also on strategic considerations and a convergence of policy positions. In the South Tyrolean two-dimensional political space, which is characterised by an economic and a territorial dimension of competition, both parties position themselves on the right and the pro-periphery side of the 
continuum. While Italian-speaking right-wing parties tended to favour re-centralization in the past, with the rise of the LN, an Italian-speaking right-wing party is now adopting a properiphery position. South Tyrol's autonomy is moving toward further integration and the strengthening of the principle of territoriality.

The article is structured as follows. The next section introduces South Tyrol's model of consociational democracy. Section three presents the most important South Tyrolean parties and their election campaign. The fourth section discusses the electoral results and analyses the impact they have had on South Tyrol's autonomy. I conclude with a discussion on coalition formation.

\section{InSTITUTIONAL AND POLITICAL CONTEXT}

The Autonomous Province of Bolzano/South Tyrol is the northernmost province of Italy and, together with the Autonomous Province of Trento, forms one of the five Italian regions with a special statute (out of 20 regions). The call for self-determination in South Tyrol was essentially silenced after the Gruber-De Gasperi agreement (or Paris Agreement) in 1946. This bilateral agreement between Austria and Italy guaranteed the German- and Ladin-speaking minority rights and protection mechanisms. The unsatisfactory implementation of the agreement by the Italian state led to violent action and attracted the attention of the UN in the 1960s following the intervention from Austria as a 'protecting power'. The negotiations culminated in the adoption of the Second Autonomy Statute in 1972. Through the transfer of the main legislative and administrative powers from the region to the province between then and 1992, when the conflict was finally settled, the Statute empowered South Tyrol with a high level of autonomy in financial, cultural and social matters.

The South Tyrolean political system corresponds to the consociational model of democracy conceptualised by Arend Lijphard. ${ }^{1}$ In order to tame centrifugal tendencies, this model reduces political competition and secures cooperation between political elites through mechanisms of power sharing. Therefore, the distribution of political power in South Tyrol only partly reflects electoral results and the majority principle is replaced by mutual guarantees for the access to

\footnotetext{
${ }^{1}$ Günther Pallaver, "South Tyrol's Consociational Democracy: Between Political Claim and Social Reality", in Jens Woelk, Francesco Palermo and Joseph Marko (eds.), Tolerance through Law: Self Governance and Group Rights in South Tyrol (Martinus Nijhoff, Leiden/Boston, 2008), 303-327.
} 
and use of power between the relevant linguistic groups. Essentially, power sharing in South Tyrol refers to the following basic principles in the Autonomy Statute of 1948: ${ }^{2}$

Maximum inclusion. The principle of inclusion expects the participation of all linguistic groups at the governmental level. Consequently, the provincial government always has to be composed according to the size of the linguistic groups represented in the provincial council. This principle is equally applied at all community levels and public representative entities.

Proportional representation. The proportional representation of all linguistic groups in political organs is achieved through a proportional electoral system and a so called "ethnic quota system" (Ethnischer Proporz). ${ }^{3}$ The latter, moreover, distributes all public sector posts and funding according to language group percentages determined by the last census (Table 1).

Veto power and decision-making autonomy. In questions, which are not of common interest (e.g. cultural and school autonomy) every language group enjoys decision-making autonomy. Veto-power is used when deciding on the defence of the vital interests of group protection and/or if established forms of conflict resolution are not sufficient.

Table 1. Population in South Tyrol according to language group percentages (1900-2011)

\begin{tabular}{cccc}
\hline Year & German & Italian & Ladin \\
\hline 1900 & 88.8 & 4.0 & 4.0 \\
1910 & 89.0 & 2.9 & 3.8 \\
1921 & 75.9 & 10.6 & 3.9 \\
1961 & 62.2 & 34.3 & 3.4 \\
1971 & 62.9 & 33.3 & 3.7 \\
1981 & 64.9 & 28.7 & 4.1 \\
1991 & 67.9 & 27.6 & 4.3 \\
2001 & 69.1 & 26.4 & 4.3 \\
2011 & 69.4 & 26.0 & 4.5 \\
\hline
\end{tabular}

Source: South Tyrolean Institute of Statistics (ASTAT) 2018.

Note: The remaining percentage points adding to 100 pertain to other linguistic groups.

The consociational model of democracy at the level of the elites is strongly related to the ethnic division of the South Tyrolean society, resulting in a highly complex space of political competition. The South Tyrolean party system is characterized by a deep ethnic cleavage that

\footnotetext{
${ }^{2}$ Günther Pallaver, "South Tyrol's changing political system: from dissociative on the road to associative conflict resolution", 42(3) Nationalities Papers (2014), 376-398.

${ }^{3}$ The ethnic quota assumes that all citizens declare themselves belonging to one of the three recognized language groups. It constitutes a subjective declaration of intent, which cannot be objectively verified.
} 
divides the electoral market into two ethnically distinct sub-arenas, whereby German- and Italian-speaking parties do not compete with each other for the most part. Traditional political conflicts (e.g. religion and class) have evolved alongside, either crosscutting or overlapping, a salient centre-periphery dimension. ${ }^{4}$ This complexity is compounded by the multilevel structure of the Italian state and its effects on the national and subnational party systems. The SVP, which sees itself as the "ethnic catch-all party for all German- and Ladin-speaking South Tyroleans", has been the dominant party in South Tyrol, governing the province for 70 years with an absolute majority of seats up until $2013 .^{5}$ This loss of an absolute majority constitutes the low point of a longer period of electoral decline, which, besides general trends in the transformation of regional politics, is due to the completion of its main policy goal (territorial autonomy) and the consequent erosion of the prioritized ethnic unity of the German and Ladin minorities above all other political conflicts.

In such a context, the consociational system begun to lose balance due to enhanced centrifugal competition, as well as major changes in the principle of inclusion of all linguistic groups. The parties benefitting from the SVP's electoral decline have up until now been rightwing secessionist movements, which emerged in opposition to the SVP's de facto abandonment of the right to self-determination after accepting the final conflict settlement in 1992. In their view, autonomy does not guarantee a permanent solution guaranteeing the linguistic-cultural survival of South Tyroleans in a foreign nation-state. The continuous electoral success of those parties puts pressure on the SVP's centre-periphery agenda, confronting the party with a dilemma regarding the question of self-determination. The SVP's realist autonomy policy, which rests upon a consensus with Austria and Italy, is not compatible with claims for secession. However, the party has responded to the challenge through a radicalization of demands from the central government, calling for "full autonomy". 6

\footnotetext{
4 Matthias Scantamburlo, "Selbstbestimmung und Parteien in Südtirol: Territoriale und europäische Parteistrategien zwischen Autonomie und Sezession", European Diversity and Autonomy Papers (2016) No. 3, 1-40.

${ }^{5}$ Matthias Scantamburlo and Günther Pallaver, "The 2013 South Tyrolean Election: The End of SVP Hegemony", 24(4) Regional \& Federal Studies (2014), 493-503.

${ }^{6}$ This strategy refers to reaching a maximum level of devolution by transferring all competences that are not assumed by the state (such as defence, foreign and monetary policy), including amongst others a full financial autonomy, an autonomous police force, and the capacity to conclude international agreements. Matthias Scantamburlo and Günther Pallaver, "Between Secession and 'Full Autonomy': Party Competition over Self-Determination in South Tyrol", Evolving Nationalism (EvoNat) Research Brief No. 3, November 2015, at <https://nationalismsinspain.com/researchbriefs/>.
} 
Changes in the principle of inclusion on the contrary refer to the under-representation of the Italian-speaking population in relevant decision-making processes, which are mainly rooted in the fragmentation of the Italian party system, as well as patterns of coalition formation. During the First Italian Republic ${ }^{7}$ the governing partners of the SVP, the Christian Democratic and Socialist Parties (DC and PSI respectively), always represented around 40 to $50 \%$ of the Italian-speakers. Centre-left governing parties since 1993, however, have not represented more than $30 \%$. This does not refer to the aforementioned (formal) proportionality rule, which has always been taken into account, but rather to political representation. Considering the centreperiphery compatibility of its coalition partners, the SVP has always ruled out parties critical toward autonomy, even when representing significant sectors of the Italian-speaking population. This was the case since the 1990s, when the majority of Italian-speakers voted for parties favouring re-centralization. Consequently, the exclusion from representation is the main driver concerning the feeling of so-called "Italian discomfort" (disagio).

While both dynamics have different roots, they question the legitimacy of the political system concerning the balance of power between the language groups. Before looking at how the 2018 election results affected those dynamics, the next section discusses the main South Tyrolean parties and their election campaign.

\section{Political Parties ANd Electoral CAMPAign}

Since the political landscape of South Tyrol is characterised by a centre-periphery dimension, regionalist parties dominate the South Tyrolean party system. Regionalist parties are parties whose political agenda is the defence of a particular territory within the nation-state. They form the regionalist or peripheral party family, as they arise from the centre-periphery cleavage and, unlike regional branches of state-wide parties, they organize exclusively in their peripheral territory. ${ }^{8}$

Regionalist parties in South Tyrol pertain almost entirely to the German-speaking intraethnic electoral arena, which is characterised by processes of "ethnic outbidding" between the moderate-conservative and autonomist South Tyrolean Peoples Party (SVP) and its right-wing

\footnotetext{
${ }^{7}$ The Italian political system underwent major changes in the 1990s so that observers distinguish between a First Republic (1946-1992) and a Second Republic (from 1993). The main differences concern the electoral market and the government/opposition dynamics in the parliamentary arena.

${ }^{8}$ Sonia Alonso, Challenging the State: Devolution and the Battle for Partisan Credibility. A Comparison of Belgium, Italy, Spain and the UK (Oxford University Press, Oxford, 2012).
} 
secessionist counterparts the Freedom Party (DF), the South-Tyrolean Freedom (STF) and the small Citizens Union (BU). The STF emerged in 2007 to campaign for a referendum on selfdetermination with the aim of reuniting the historical Tyrol (i.e. north and south) under a common Austrian roof. The DF, on the contrary, was modelled on the right-wing populist Austrian Freedom Party (FPÖ) and became the SVP's major challenger, promoting the creation of an independent South Tyrolean free state. In the run-up to the 2018 election, this constellation changed with the rise of Team Köllensperger (TK), named after the main leader and former Five Star Movement (M5S) candidate Paul Köllensperger. The TK is clearly inspired by the tradition of non-partisan (or civic) lists that have grown considerably at the local level since the 1990s and reflects the increasing distrust in traditional political actors. Contrary to the territorially based Greens (GVV), who organize inter-ethnically, the TK can be considered as a German-speaking party. ${ }^{9}$ Like the SVP, it adopts a pro-autonomy position and rejects independence.

Though dominated by regional branches of state-wide parties, the Italian-speaking intraethnic arena reflects the national party system and has adopted a tri-polar type of competition. This has occurred in light of the electoral growth of the Five Star Movement (M5S), which, since 2013, has challenged both the Italian traditional left and right. The centre-left pole is occupied by the Democratic Party (PD) and to some extent by the Greens, who have also gained support in the Italian-speaking intra-ethnic arena. The major parties pertaining to the centreright are Forward Italy (FI), the Northern League (LN) and Alto Adige in the Heart (AAnC). The AAnC can be considered as a territorial list and the main successor of the state-wide nationalist party National Alliance (AN). Although party competition mainly takes place on the economic left-right dimension, the centre-left parties have historically adopted autonomy friendly positions, whereas the centre-right has been hostile towards more autonomy from Rome, with the notable exception of the LN. Despite being a pro-federalist party, the LN never played an important role in South Tyrol as the claim to represent the whole of the Italian North (i.e. Padania) was not supported in the territory (at the 2013 election it did not even participate on its own, but within the right-wing coalition Team Autonomy (TA) obtaining just 2.5\%). Yet it's transformation into a state-wide populist radical right party under the leadership of Matteo

\footnotetext{
${ }^{9}$ The list is externally perceived as German-speaking, the internal and external communication language is predominantly German, and its members and voters come almost exclusively from the German language group.
} 
Salvini has made it an important player within South Tyrol's Italian-speaking electorate in the run-up to the 2018 election.

Figure 1. Party system agenda in South Tyrol 2013-2018.

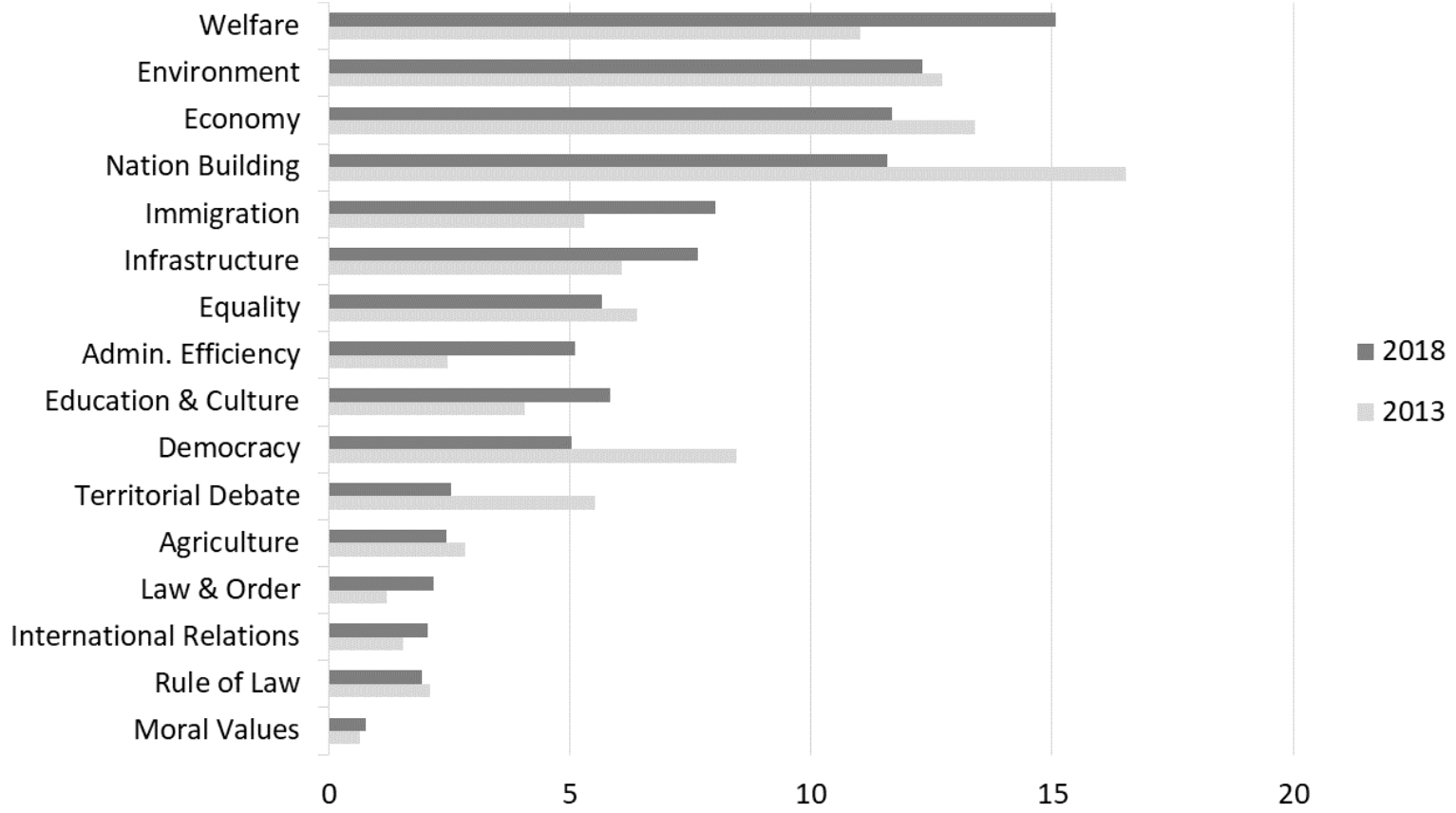

Source: Regional Manifestos Project.

Figure 2. Saliency scores of general issues in 2018 South Tyrolean parties' manifestos.

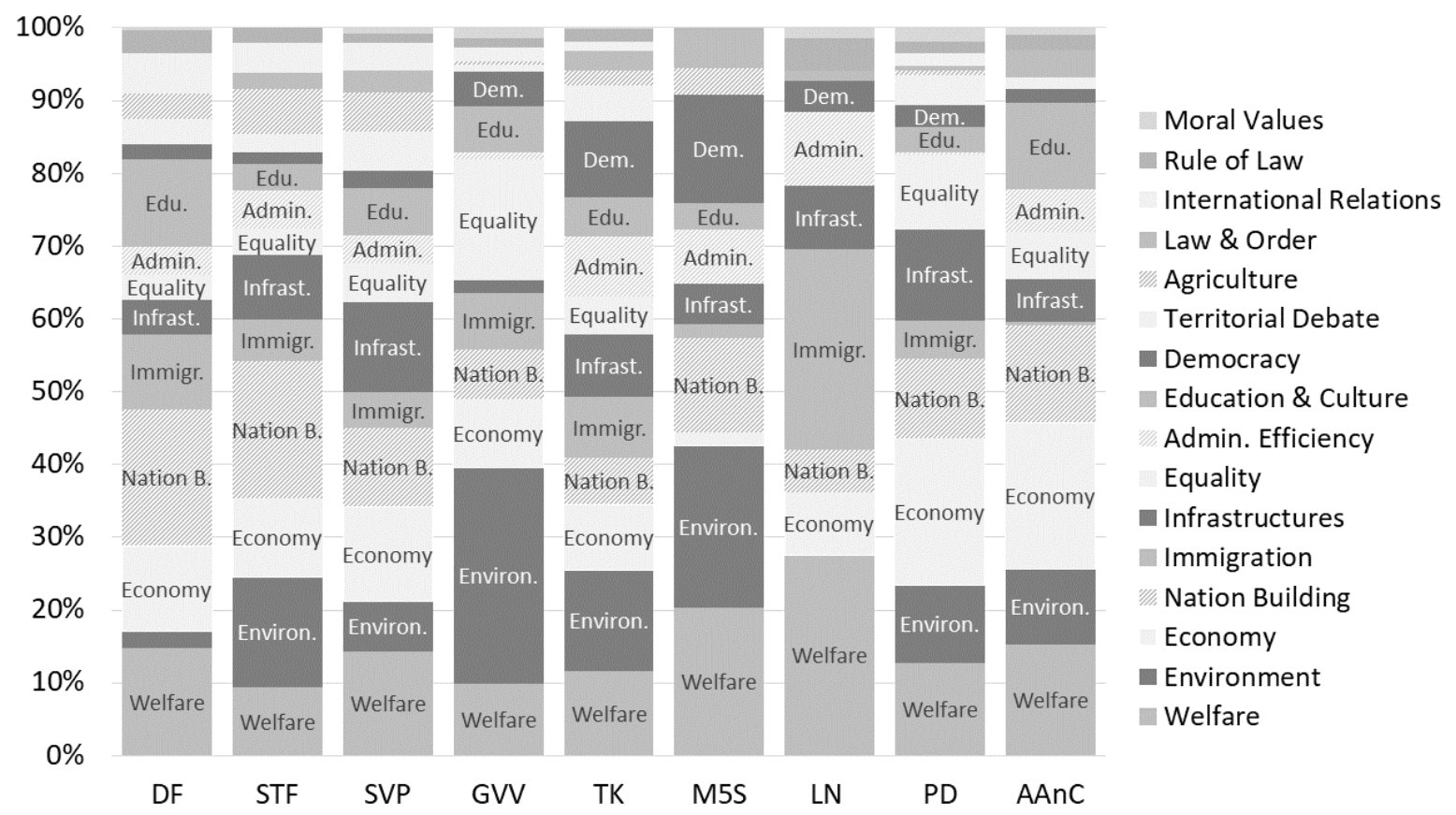

Source: Regional Manifestos Project. 
In order to account for the issues deemed most important for the South Tyrolean parties' 2018 campaign, this article uses data from the content analysis of their electoral manifestos. More concretely, I rely on the data of the Regional Manifestos Project (RMP), an adaption of the Manifesto Project's (MP) methodology for the analysis of multilevel polities. ${ }^{10}$ Figure 1 shows the most salient issues in the South Tyrolean party system. ${ }^{11}$ In their manifestos, the parties dedicated most space to welfare and the environment. Issues pertaining to the traditional themes, such as the economy, nationalism or the territorial debate were less important in 2018, although they still figure strongly compared to other topics. As expected, immigration and the investment in infrastructure and technology were also highly discussed. Comparing the party system agenda with the past election of 2013, welfare, immigration, infrastructure, administration, education and culture were those issues that gained higher in 2018. The traditional issues of nation-building, the territorial debate and, to a lesser extent, the economy, have lost relevance, as well as the debate over the renewal of the province's democratic practices.

Looking at the differences between political parties (for a detailed comparison between 2013 and 2018 see Table A2 in the appendix) one can observe that nationalism and the territorial debate were of major importance among the German-speaking regionalist parties. As already observed in past elections, ${ }^{12}$ the secessionist parties STF and DF put more emphasis on nation building, and the SVP focused more on issues concerning competences (territorial debate). In addition to this, the focus on international relations (with Austria) and agriculture as important issues for their traditional voter bases differentiated them from their Italian-speaking counterparts. As to be expected, the Greens gave more space to issues concerning environmental protection (30\%) in their 2018 manifesto than any other party. The new challengers TK and M5S, and partly also the LN, stood out for their campaign for a regeneration of democratic practices (between $12 \%$ and $15 \%$ of the manifesto). Italian-speaking

\footnotetext{
${ }^{10}$ Sonia Alonso, Braulio Gómez and Laura Cabeza, "Measuring Centre-Periphery Preferences: The Regional Manifestos Project", in 23(2) Regional \& Federal Studies (2013), 189-211. For further explanation about methodology and coding scheme see: <www.regionalmanifestosproject.com>. ${ }^{11}$ For the analysis, I grouped the RMP 76 policy categories into 16 general issues following the examples of the RMP team. In order to describe the "issue package" of a party, it is better to aggregate some of the more specific categories of the classification scheme into broader issues, which should not differ excessively in terms of their generality. See: Sonia Alonso, Laura Cabeza and Braulio Gómez, "Disentangling peripheral parties' issue packages in subnational elections", 15(2) Comparative European Politics (2017), 240-263.

${ }^{12}$ Matthias Scantamburlo, "Partiti e autodeterminazione in Alto Adige/Südtirol. Competizione etnica e strategie dei partiti tra autonomia e secessione", Nazioni e Regioni (2016) No. 7, 47-70.
} 
establishment (AAnC and PD) and challenger (LN and M5S) parties differentiated themselves especially according to the latter's dismissal of economic issues. While LN and M5S both strongly focused on welfare, the LN, more than any other party, campaigned on (and against) immigration $(27.5 \%$ of the manifesto).

\section{ELECTION RESUlTS AND DisCUSSION}

The Landtag election of 21 October 2018 saw the participation of $73.9 \%$ of the eligible voting population (the lowest figure ever in the history of South Tyrol, 3.8\% down on the then all-time low turnout in 2013). According to Table 2, the party that received the most votes was the SVP, which, in line with pre-electoral expectations, gathered $41.9 \%$ of the popular vote. Losing $3.8 \%$ of the previous vote and only winning 15 seats (compared to 17 in 2013), the SVP continues its slow but continuous decline. It still, however, managed to avoid finishing under the important threshold of $40 \%$. The main winner of the election was the TK, which became the provincial council's second party, gathering $15.2 \%$ of the votes and 6 seats. Although the party presented itself as inter-ethnic movement, all 6 seats went to candidates from the German linguistic group, thus heavily affecting the party's coalition potential.

Table 2. Summary of the 2018 South Tyrolean Landtag election results

\begin{tabular}{|c|c|c|c|c|c|}
\hline \multirow{2}{*}{ Party } & \multicolumn{3}{|c|}{ Popular Votes } & \multicolumn{2}{|c|}{ Seats } \\
\hline & Votes & $\%$ & $+/-$ & Seats & $+/-$ \\
\hline $\begin{array}{l}\text { SVP } \\
\text { South Tyrolean Peoples Party }\end{array}$ & 119.109 & 41.9 & -3.8 & 15 & -2 \\
\hline $\begin{array}{l}\text { TK } \\
\text { Team Köllensperger }\end{array}$ & 43.315 & 15.2 & +15.2 & 6 & +6 \\
\hline $\begin{array}{l}\text { LN } \\
\text { Northern League - League }\end{array}$ & 31.515 & 11.1 & +8.6 & 4 & +3 \\
\hline $\begin{array}{l}\text { GVV } \\
\text { The Greens }\end{array}$ & 19.392 & 6.8 & -1.9 & 3 & $=$ \\
\hline $\begin{array}{l}\text { DF } \\
\text { Freedom Party }\end{array}$ & 17.620 & 6.2 & -11.8 & 2 & -4 \\
\hline $\begin{array}{l}\text { STF } \\
\text { South-Tyrolean Freedom }\end{array}$ & 16.927 & 6.0 & -1.2 & 2 & -1 \\
\hline $\begin{array}{l}\text { PD } \\
\text { Democratic Party }\end{array}$ & 10.808 & 3.8 & -2.9 & 1 & -1 \\
\hline $\begin{array}{l}\text { M5S } \\
\text { Five Star Movement }\end{array}$ & 6.670 & 2.4 & -0.1 & 1 & $=$ \\
\hline $\begin{array}{l}\text { AAnC-FdI } \\
\text { Alto Adige in the Heart-Brothers of Italy }\end{array}$ & 4.882 & 1.7 & -0.4 & 1 & $=$ \\
\hline Voter turnout & 282.878 & 73.9 & -3.8 & & \\
\hline
\end{tabular}

Source: Electoral results, Provincial Council of the Autonomous Province of South Tyrol.

Note: In 2013 the LN participated within the coalition Team Autonomy (TA). 
Table 3. Volatility and Effective Number of Parliamentary Parties (ENPP) (1988-2018)

\begin{tabular}{cccccccc}
\hline & 1988 & 1993 & 1998 & 2003 & 2008 & 2013 & 2018 \\
\hline Volatility & 17.45 & 22.3 & 14.75 & 13.6 & 24.6 & 21.75 & 28.35 \\
ENPP & 2.37 & 3.09 & 2.63 & 2.60 & 3.28 & 3.49 & 4.12 \\
\hline
\end{tabular}

Source: Electoral results, Provincial Council of the Autonomous Province of South Tyrol.

Note: Volatility is calculated according to the Pedersen Index of Electoral Volatility. The Effective Number of Parliamentary Parties (ENPP) is calculated according to Laakso and Taagepera's Index.

Amongst the winners, the LN must certainly be mentioned, with an increase of $8.6 \%$ of the popular vote vis-à-vis 2013 (when it ran inside the Italian-speaking centre-right coalition Team Autonomy) and now the largest political force amongst Italian-speaking parties. The main losers of the election were the German-speaking secessionist parties. The most impressive breakdown was that of the DF, which lost $11.7 \%$ (from $17.9 \%$ down to $6.2 \%$ ), won only 2 seats (compared to 6 in 2013) and returned to the performances of the early 1990s, when the party split from the SVP. The STF did not lose many votes $(-1.2 \%)$ but failed to obtain a third mandate. The smallest secessionist party, BU, for the first time failed to obtain representation. When it comes to the losers, one cannot avoid Italian-speaking mainstream parties. The PD dropped back to $3.8 \%$ ( $-2.9 \%$ as compared to 2013) and obtained the worst result in its (short) history. Although numerically this was enough for it to score as the second Italian-speaking party, the loss of one mandate heavily weakened its potential as a coalition partner. Its rightwing counterpart FI did even worse and did not move into the Landtag.

The political situation after the 2018 election is marked more by change than continuity. Although the trend towards an increasing volatility and fragmentation of the party system (see Table 3), as well as the electoral decline of the dominant SVP, have been constant features of South Tyrolean politics since 2003, the outcome of the 2018 election inverted different trends that had become visible over the last couple of years. First, contrary to past elections, all parties of the establishment have been punished, while new challenger parties have become serious competition. Second, the German-speaking secessionist parties, which were on a continuous rise over the last 15 years, have lost mass support. Third, a higher number of Italian-speaking MPs entered the Landtag, thus improving the representation of Italian-speakers. In order to account for those processes and evaluate their impact on the consociational system, different political dynamics must be outlined. 


\section{A. Establishment Parties vs. (New) Challengers}

Looking at the electoral results, we can see that the only parties to increase their vote share were new or renewed in their agenda. All other parties lost votes. In this respect, an increasing distrust of traditional party actors and processes shaped the 2018 election. According to the last survey on citizen satisfaction with public services, trust in the political class continues to be amongst the lowest categories and only one citizen in three feels involved in the provincial decisionmaking processes. ${ }^{13}$ The lack of alternation in regional office for extremely long periods, as in the case of South Tyrol, raises questions about democracy, making the regeneration of democratic practices an area of political competition. Major political or economic crises can increase such a dimension and accelerate pre-existing long-term processes of party system change. ${ }^{14}$ While growing distrust towards politics in South Tyrol can be traced back to the beginning of the economic crisis, ${ }^{15}$ the pension scandal of 2014, where pension reforms allowed politicians to claim up to millions of euros, cast a long shadow over the whole political establishment. ${ }^{16}$ Indeed, voters did not only punish the governing parties, but also, and more fundamentally, they defected from the main traditional opposition. TK's transformative agenda resonated with voters by offering something that the traditional opposition could not offer anymore: democratic renewal (see section 3).

\section{B. Autonomy vs. Secession}

Strongly connected to the growing disaffection towards traditional parties is the change in political structuring and its effects on traditional political divides in driving voters' choices. In South Tyrol, the traditional left-right dynamic has evolved along a salient centre-periphery dimension, shaping political competition. If we look at the South Tyrolean party system with regards to proximity or distance to autonomy, it becomes clear that a centrifugal tendency has been visible over the last two decades, with an enhanced competition around the centre-

\footnotetext{
${ }^{13}$ ASTAT "Zufriedenheit der Bürger mit den öffentlichen Diensten", Astat Info No. 55, September 2018, at <https://astat.provinz.bz.it>.

${ }^{14}$ Matthias Scantamburlo, Alonso Sonia and Braulio Gómez, "Democratic Regeneration in European Peripheral Regions: New Politics for the Territory?" 41(3) West European Politics (2018), 615-639.

${ }^{15}$ Gernot Gruber, "Zwei Landtagswahlen im Lichte der Meinungsforschung", in Günther Pallaver (eds.) Politika14. Südtiroler Jahrbuch für Politik (Nomos, Baden-Baden, 2014), 195-224.

${ }^{16}$ When the privileged procedures became known a storm of indignation rose in civil society addressing all parties, government and opposition alike, because all MPs had or would had benefitted from the reform. Only the M5S, which was elected in 2013, thus after the reform, had been excluded from criticism.
} 
periphery dimension. ${ }^{17}$ While secessionist parties accounted for $27 \%$ of the popular vote in 2013, those parties only reached $12 \%$ in $2018 .{ }^{18}$ With the rise of the TK, which adopts an autonomist position, voter support in the German-speaking intra-ethnic arena has moved away from secession and now orients itself more towards the status quo. The causes for such an evolution partly stem from territorial and anti-establishment politics and the SVP's successful centre-periphery agenda. The violations of South Tyrol's constitutionally guaranteed financial autonomy amid Italian post-crisis austerity efforts during the technocratic Monti government (2011-2013) caused political discontent with the SVP's territorial agenda and strengthened the DF's and STF's framing of the anti-establishment rhetoric in secessionist terms. The SVP's "full autonomy" discourse since 2013, combined with successful negotiations at the national level, ${ }^{19}$ not only provided security from centralist tendencies, but also permitted the argument that South Tyrol's autonomy was on a better footing than it was before. Thus, it gave credibility to the autonomist path and the possibility to negotiate for further competences. Moreover, with the rise of the TK the German-speaking electorate, for the first time, had a new and viable autonomist alternative to the SVP.

\section{Representation of Italian-speakers}

The principle of the maximum inclusion of all language groups in the decision-making process has undergone profound changes in the past two decades due to radical changes in Italian party politics. Interrelated causes such as the strong party fragmentation, the decline in turnout among the Italian-speaking electorate and a decline in the coalition potential of Italian-speaking parties led to an underrepresentation of the Italian-speakers in decision-making institutions in terms of their numerical strength. One main consequence of such development has been the feeling of "Italian discomfort" (disagio). In 2013 the number of Italian-speaking MPs dropped to five, which resulted in only one representative in the South Tyrolean government ${ }^{20}$, but this increased to eight after the 2018 elections, enabling the Italian group to send two representatives to the government again. With two representatives in nine, the Italian language group is represented

\footnotetext{
${ }^{17}$ Scantamburlo op.cit. note 5.

${ }^{18}$ Scantamburlo and Pallaver op.cit. note 6.

${ }^{19}$ E.g. the "security pact", a financial agreement to prevent the arbitrary access of the state to provincial funds, or the "safeguard clause", which exempted South Tyrol from Prime Minister Renzi's failed centralist constitutional reform. Although the majority of the Italian population rejected the reform in a referendum held in 2016 , with $63.7 \%$ of the votes in favour $(6 \%$ higher than any other province) South Tyrol was the strongest supporter of the constitutional reform.

${ }^{20}$ With only $4.5 \%$ of the population and 1 member in the government, the Ladin group was equally represented.
} 
at $22.2 \%$ in the provincial executive, slightly below its numerical strength of $26 \%$ (according to the 2011 census), but a huge improvement on the previous $12.5 \%$. Such an improvement in political influence is mainly owed to the electoral success of the LN. Indeed, it collected almost all the votes received in the past by the Italian-speaking right-wing parties, the AN and FI, thus reunifying the Italian-speaking centre-right electoral space. While the rise of the TK led to a shift towards more moderate positions in the German-speaking intra-ethnic arena, on both the territorial and economic dimensions, with the success of the LN and the losses of the PD, the Italian intra-ethnic arena again shifted towards the right. However, given its past federalist and generally autonomy friendly positions, contrary to the former elections, for the first time an Italian-speaking right-wing party had a stronger coalition potential. This, as I show below, has had important implications for government formation.

To sum up, concerning the consociational system of democracy, the changing political dynamics had a differential impact. In the German-speaking arena, the rise of new challengers and the changing dynamics in party competition contributed to a further reduction in the SVP's dominance and consequently its ability to represent the German-speaking community. Yet, after years of centrifugal tendencies, with the rise of the TK, competition moved towards a centripetal dynamic. As a result, the polarization concerning autonomy has decreased and exit options have partly been replaced by loyalty. The realignments in the Italian-speaking arena had quite the opposite effect. With the mechanics of the party system remaining stable, the rise of the LN mainly replaced the former right-wing parties and contributed to an increase in the number of Italian-speaking MPs. Consequently, despite the SVP's decreasing ability to dominate the German-speaking constituency, the centripetal dynamics and the increasing number of Italianspeaking MPs point to a stabilization of the consociational system.

\section{GOVERNMENT FORMATION}

According to the Autonomy Statute of 1948, all linguistic groups have to be represented in the South Tyrolean government according to their proportional strength in the provincial council. With eight mandates in the provincial council after the election of 21 October, the Italian group is by law entitled to two seats in the government. In addition, a gender quota establishes two seats for female representatives. Special rules apply to the Ladin group, which has a guaranteed right to be represented in the provincial council, but needs at least two deputies to get a seat in the provincial government. In 2018, two Ladin-speaking MPs were elected among the ranks of 
the SVP, so that after decades they now had the right to be represented in the provincial government on their own terms. ${ }^{21}$

As the strongest party, the SVP needed an Italian-speaking coalition partner to form a government. Taking into account the principle of ethnic proportionality in the past two legislatures, the SVP formed a coalition with the PD but the outcome of the 2018 election produced no majority for such a possibility. The only feasible coalitions were either with the LN, which was the party elected by the majority of Italian-speakers, or a coalition with the PD and the Greens, since the Greens sent one Italian-speaking representative to the Landtag. A third variant would have been an Italian-speaking party entering government without a coalition agreement. $^{22}$

For the SVP both combinations brought about political dilemmas. The biggest problem of a coalition with the LN was its position on the EU and its right-wing populist character. While the LN is a Eurosceptic party, the SVP is decidedly Europhile. Moreover, the SVP is quite far away from the LN's anti-immigrant discourse. On the other hand, a coalition with the Greens and the PD would have represented a much smaller section of the Italian linguistic group. The SVP also has big reservations about the Green's inter-ethnic character (i.e. conflict about bilingual schools). After the first discussion rounds with the three parties, the SVP party steering committee voted in favour to open negotiations with the LN (65 votes in favour, 11 against and 7 abstentions). The prerequisite for starting negotiations, however, was the LN's explicit commitment to democratic values, the further development of autonomy and to a Europe of the Regions as a guarantee of security, peace and prosperity. ${ }^{23}$ After longer negotiations (and rejections by the $\mathrm{LN}$ ), these commitments were introduced in the preamble of the coalition agreement. On 8 January 2019, the coalition agreement was signed by the leaders of all participating parties, and on 25 January the Landtag elected Arno Kompatscher to his second term as governor - three months after the election. The SVP-LN government, for the first time since the final conflict settlement in 1992, represents a higher number of the Italian-speaking voting population in South Tyrol (see Table 3).

\footnotetext{
${ }^{21}$ If the Ladin minority group does not get at least two seats the possibility of co-opting into the provincial government is still given but requires a two-thirds majority.

${ }^{22}$ Such a solution existed for a short time during the legislature period from 1973 to 1978.

${ }^{23}$ See coalition agreement between SVP and Lega Salvini Alto Adige-Südtirol 2018-2023, at $<$ https://www.salto.bz/sites/default/files/atoms/files/regierungsvereinbarung svp-lega.pdf>.
} 
Table 4. Vote share of Italian-speaking governing parties according to the Italian-speaking voting population

\begin{tabular}{cccc}
\hline Legislature & $\begin{array}{c}\text { German- and Ladin- } \\
\text { speaking coalition party }\end{array}$ & $\begin{array}{c}\text { Italian-speaking } \\
\text { coalition party }\end{array}$ & $\begin{array}{c}\text { \% Italian-speaking } \\
\text { governing parties }\end{array}$ \\
\hline $1948-1952$ & SVP & DC, PRI & 42,7 \\
$1952-1956$ & SVP & DC & 38,9 \\
$1956-1960$ & SVP & DC & 40,4 \\
$1960-1964$ & SVP & DC & 38,9 \\
$1964-1968$ & SVP & DC, PSDI & 44,8 \\
$1968-1973$ & SVP & DC & 39 \\
$1973-1978$ & SVP & DC, PSI & 53,7 \\
$1978-1983$ & SVP & DC, PSDI & 40,2 \\
$1983-1988$ & SVP & DC, PSI & 42,1 \\
$1988-1993$ & SVP & DC, PSI & 40,2 \\
$1993-1998$ & SVP & PPI, PDS & 23,3 \\
$1998-2003$ & SVP & DS, PPI, Centro & 27,8 \\
$2003-2008$ & SVP & PeD, UA & 27,6 \\
$2008-2013$ & SVP & PD & 23,9 \\
$2013-2018$ & SVP & PD & 29,5 \\
$2018-$ & SVP & LN & 44,6 \\
\hline
\end{tabular}

Source: Adapted from Günther Pallaver, "Das politische System Südtirols: Komplexe Machtteilung und ethnische Einflussspähren", in: Hermann Atz, Max Haller and Günther Pallaver (eds.), Ethnische Differenzierung und soziale Schichtung in der Südtiroler Gesellschaft (Nomos, Baden-Baden, 2016), 61-80.

From the perspective of the consociational principle of the maximum inclusion of language groups, the LN's government participation has contributed even further to bringing the Italianspeaking population back into the system and thereby to its stabilization. After the 2018 election, the Italian-speaking government party represents $44.6 \%$ of its own segment, a quota that was last reached in the 1970s. While the representation of the linguistic groups is an important factor, it explains only a part of the story about the patterns of coalition formation. In order to account for them, it is worth bearing in mind strategic considerations concerning coalition formation. Political parties may be assumed to seek three interrelated goals: votes, office and policy, all of them having straightforward implications for the formation of government coalitions. ${ }^{24}$ Parties should attempt to form coalitions that do not harm them electorally, and that allow them to control as many cabinet posts as possible and implement as many of their policy proposals as possible. How parties weight these different priorities is dependent on the political context. ${ }^{25}$ Leaving aside the South Tyrolean peculiarities, such as the

\footnotetext{
${ }^{24}$ Kaare Strøm and Wolfgang C. Müller (eds.), Policy, Office, or Votes? How Political Parties in Western Europe Make Hard Decisions (Cambridge University Press, Cambridge, 1999).

${ }^{25}$ Wolfgang C. Müller, "Government formation", in Todd Landmann and Neil Robinson (eds.), The SAGE Handbook of Comparative Politics (Sage Publications, Los Angeles, 2009), 227-245.
} 
ethnic representation principle and the a priori rejection of parties rejecting autonomy, actual patterns of government formation in multi-level democracies can expect coalitions if they (1) consist of a small number of parties (2) are characterised by a low heterogeneity of parties' policy positions in key dimensions (3) are congruent with coalitions at other government levels. $^{26}$

Figure 3. Party policy positions 2013-2018 on the centre-periphery and left-right dimensions.

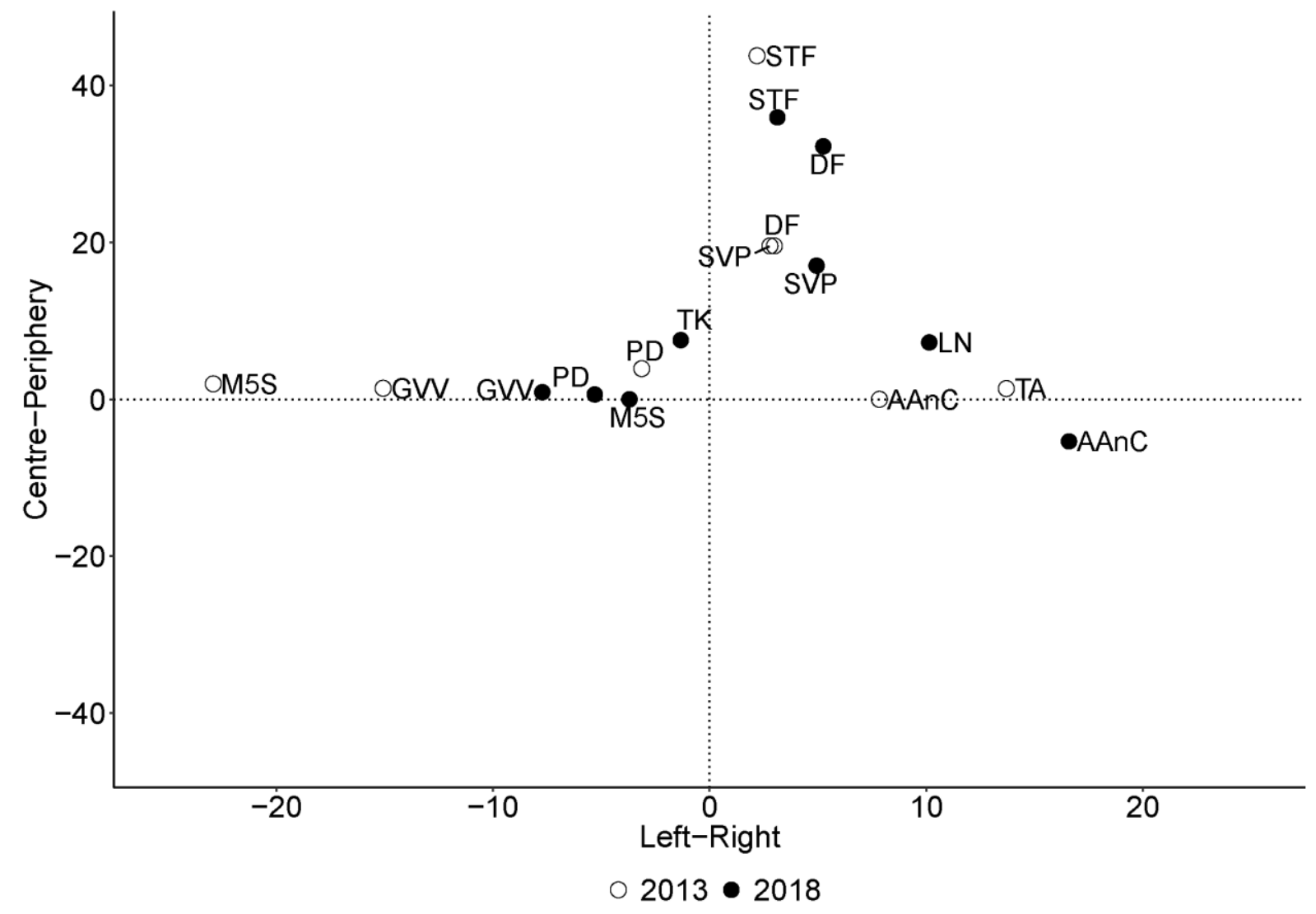

Source: Regional Manifestos Project.

Note: In 2013 the LN participated within the coalition Team Autonomy (TA).

While it is difficult to weight the different priorities in the case of the 2018 negotiations, a coalition between SVP and LN was the most likely one from a strategic perspective. Forming an executive with the Greens and the PD would have consisted of a greater number of parties, a higher heterogeneity of policy positions in key dimensions and would have been less congruent with the coalition at the national level. Figure 3 shows the evolution of party policy

${ }^{26}$ Thomas Bräuninger, Marc Debus, Jochen Müller and Christian Stecker, "Party Competition and Government Formation in Germany: Business as Usual or New Patterns?", in 28 (1) German Politics (2019), 80-100. 
positions on the two traditional conflict dimensions characterising political competition in South Tyrol, the socioeconomic left-right and the centre-periphery dimensions, between 2013 and 2018. ${ }^{27}$ According to Figure 3, the gap between the SVP and the Greens was still too wide after the 2018 elections, on both the left-right and the centre-periphery dimensions. The LN's positions on the contrary seemed to be far more compatible with those of the SVP. Both parties occupy the political space on the right and on the pro-periphery side of the continuum and they are closer to one another as to any other party. Although new conflict dimensions, such as immigration, have increased and the position on the EU is a major conflict point, the centreperiphery and economic dimensions of competition continue to be the most important ones for the SVP and consequently the LN was the most likely option for a governing coalition.

\section{CONCLUDING REMARKS}

The aim of this article was to explore the main changes in the South Tyrolean parties and party system following up to the 2018 elections and to explore their impact on the consociational system of democracy. The outcomes of the 2018 elections confirmed different processes of change, which make South Tyrol more similar to other European (minority) regions. The SVP, which up until 2008 had always gathered an absolute majority of votes, continued its electoral decline, falling to a historical low point of $40 \%$. This shows that ethnic unity between the German and Ladin minorities above all other political conflicts has become more fragile. The citizens base their voting primarily on subjective political interests and preferences, and less on ethnic criteria. This trend is confirmed by an increasing electoral volatility, the fragmentation of the party system, the decline of traditional party loyalties and the rise of (new) challenger parties.

Concerning the configuration of the consociational system of democracy, the situation after the 2018 election is marked by an increasing stability, as different trends affecting its balance have been inverted. First, the massive loss in support for the German-speaking secessionist parties and the rise of the new party TK, which clearly adopts an autonomist position and has helped tame the centrifugal dynamics visible over the past decade. Second, the higher number of Italian-speaking MPs in the Landtag and the SVP-LN coalition, which since the early 1990s represents an increasing percentage of Italian-speakers, have significantly improved the principle of maximum inclusion of the language groups. This improvement, however, is

\footnotetext{
${ }^{27}$ The dimensions are measured according to the established, though no doubt controversial, right-left (RILE) and the centre-periphery (CP) variable, operationalised by the RMP team and whose categories are listed in the Appendix.
} 
accompanied by the decreasing ability of the SVP to represent the German-speaking community. Ultimately, the new executive rests also on a convergence in party policy positions, with a particular novelty being the pro-peripheral position of an Italian-speaking right-wing party.

While these developments point towards a further integration between the three language groups and the strengthening of the territoriality principle, the consequences of accommodating the agenda of a right-wing populist party like the LN, which favours the integration of the autochthonous language groups while promoting the exclusion of "others", remain to be seen. 
VII. APPENDIX

Table A1: General policy issues

\begin{tabular}{ll}
\hline General issue & RMP's policy categories (codes)* \\
\hline International Relations & $101,102,103,104,105,106,107,108,109,110$ \\
Territorial Debate & $1017,1027,203,204,301,3012,3013,3014,302$ \\
Administrative Efficiency & 303 \\
Democracy & $202,2024,2025,304$, \\
Rule of Law & $201,3031,305$ \\
Environmental protection & 416,501 \\
Equality & $503,705,706$ \\
Culture & 502 \\
Education & 506,507 \\
Welfare & 504,505 \\
Nation Building & $601,6015,6016,6017,602,608,606,7054$ \\
Moral Values & 603,604 \\
Law \& Order & 605 \\
Immigration & $607,608,5032,5042,5051,5062,5071,6051,7053$ \\
Agriculture & 703 \\
Economy & $401,402,403,404,405,406,407,408,409,410$, \\
& $411,4111,412,413,414,415,701,702,704$ \\
\hline
\end{tabular}

*For a full list of the categories' definitions and their respective codes, please visit the RMP project's website: www.regionalmanifestosproject.com .

Table A2. Change in general policy issue salience by party (2013-2018)

\begin{tabular}{lcccccccc}
\hline Party & DF & STF & SVP & GVV & PD & M5S & LN & AAnC \\
\hline Welfare & 4.37 & -1.57 & 2.65 & -0.49 & 2.62 & 14.95 & 4.25 & 9.24 \\
Environment & -9.13 & 3.43 & 0.62 & 5.76 & 3.56 & -11.28 & -8.22 & 10.24 \\
Economy & 3.57 & 3.64 & -1.46 & -4.77 & 3.06 & -15.64 & -7.74 & 8.24 \\
Nation Building & 6.37 & -13.37 & -1.05 & 0.54 & -3.16 & 10.25 & -7.90 & -26.04 \\
Immigration & -1.53 & -0.84 & 2.51 & 2.54 & 0.61 & 0.87 & 20.69 & -3.43 \\
Infrastructure & -0.24 & 1.55 & 2.72 & -4.33 & 6.99 & -1.34 & 4.59 & 1.93 \\
Equality & -3.69 & -2.19 & -5.17 & 8.51 & 2.47 & -0.99 & -6.85 & 2.42 \\
Administrative Efficiency & 2.15 & 5.21 & -0.21 & -0.18 & 0.31 & 6.67 & 6.04 & -1.99 \\
Culture & 9.01 & 0.00 & 0.52 & 4.56 & -0.48 & -1.72 & -6.85 & 9.75 \\
Democracy & -7.58 & -4.28 & -1.99 & -5.54 & -3.13 & -5.38 & 2.98 & -7.85 \\
Territorial Debate & -1.09 & 1.87 & -2.50 & -1.12 & -13.92 & -1.72 & -1.37 & -6.38 \\
Agriculture & -3.89 & 5.52 & 3.87 & -6.39 & 0.62 & 0.26 & -2.74 & 0.00 \\
Law \& Order & -1.80 & -0.84 & 2.34 & 0.00 & 0.62 & 5.56 & -2.66 & 3.90 \\
International Relations & 4.10 & 2.71 & -2.81 & 0.88 & 0.31 & -0.25 & 0.00 & 0.00 \\
Rule of Law & 0.06 & -0.11 & 0.95 & -0.16 & -1.57 & -0.25 & 4.35 & -0.01 \\
Moral Values & -0.95 & -0.73 & -0.24 & 0.18 & 1.09 & 0.00 & 1.45 & 0.98 \\
\hline Sourc: Region
\end{tabular}

Source: Regional Manifestos Project.

Note: The LN's change is calculated with the 2013 values of the coalition Team Autonomy (TA). 
Table A3. Calculation of scales

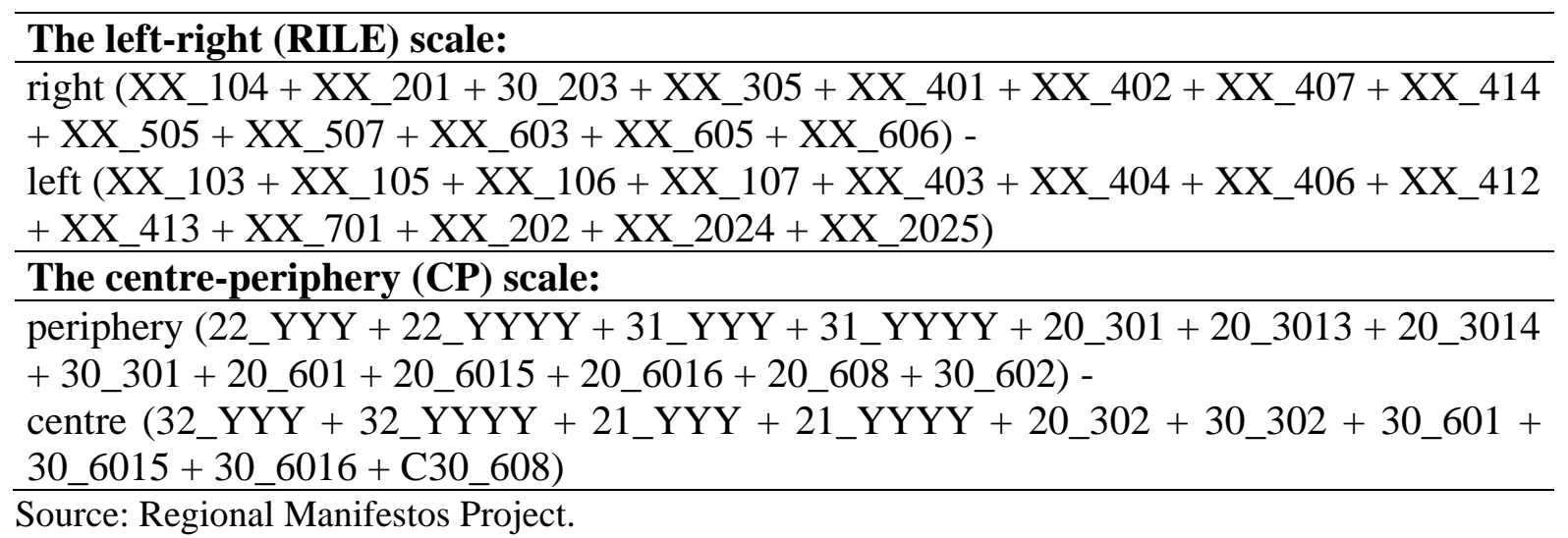




\section{REFERENCES}

Alonso, Sonia (2012) Challenging the State: Devolution and the Battle for Partisan Credibility. A Comparison of Belgium, Italy, Spain and the UK. Oxford: Oxford University Press.

Alonso, Sonia, Braulio Gómez, \& Laura Cabeza (2013) Measuring Centre-Periphery Preferences: The Regional Manifestos Project. Regional \& Federal Studies 23 (2), 189211.

Alonso, Sonia, Laura Cabeza, \& Braulio Gómez (2017) Disentangling Peripheral Parties' Issue Packages in Subnational Elections. Comparative European Politics 15 (2), 240-263.

ASTAT (2018) Zufriedenheit der Bürger mit den öffentlichen Diensten, Astat Info No. 55, at https://astat.provinz.bz.it.

Bräuninger, Thomas, Marc Debus, Jochen Müller, \& Christian Stecker (2019) Party Competition and Government Formation in Germany: Business as Usual or New Patterns? German Politics 28 (1), 80-100.

Gruber, Gernot (2014) Zwei Landtagswahlen im Lichte der Meinungsforschung. In: Günther Pallaver (ed.) Politika14. Südtiroler Jahrbuch für Politik. Baden-Baden Nomos, 195-224.

Müller, Wolfgang C. (2009) Government formation. In: Landmann, Todd, \& Neil Robinson (eds.) The SAGE Handbook of Comparative Politics. Los Angeles: Sage Publications, 227245.

Pallaver, Günther (2008) South Tyrol's Consociational Democracy: Between Political Claim and Social Reality. In: Jens Woelk, Francesco Palermo, \& Joseph Marko (eds.) Tolerance through Law: Self Governance and Group Rights in South Tyrol. Leiden/Boston: Martinus Nijhoff, 303-327.

Pallaver, Günther (2014) South Tyrol's changing political system: from dissociative on the road to associative conflict resolution. Nationalities Papers 42 (3), 381-382.

Scantamburlo, Matthias (2016) Partiti e autodeterminazione in Alto Adige/Südtirol. Competizione etnica e strategie dei partiti tra autonomia e secessione. Nazioni e Regioni 7 , 47-70.

Scantamburlo, Matthias (2016) Selbstbestimmung und Parteien in Südtirol: Territoriale und europäische Parteistrategien zwischen Autonomie und Sezession. European Diversity and Autonomy Papers 3, 1-40.

Scantamburlo, Matthias, \& Günther Pallaver (2014) The 2013 South Tyrolean Election: The End of SVP Hegemony. Regional \& Federal Studies 24 (4), 493-503.

Scantamburlo, Matthias, \& Günther Pallaver (2015) Between Secession and 'Full Autonomy': Party Competition over Self-Determination in South Tyrol. Evolving Nationalism (EvoNat) Research Brief 3 https://nationalismsinspain.com/researchbriefs/.

Scantamburlo, Matthias, Alonso Sonia, \& Braulio Gómez (2018) Democratic Regeneration in European Peripheral Regions: New Politics for the Territory? West European Politics 41 (3), 615-639.

Strøm, Kaare, \& Wolfgang C. Müller (1999) Policy, Office, or Votes? How Political Parties in Western Europe Make Hard Decisions. Cambridge: Cambridge University Press.

SVP and Lega Salvini Alto Adige-Südtirol (2018) Regierungsvereinbarung zwischen Südtiroler Volkspartei und Lega Salvini Alto Adige-Südtirol für die Legislaturperiode 2018-2023 https://www.salto.bz/sites/default/files/atoms/files/regierungsvereinbarung_svp-lega.pdf. 